KESEHATAN IBU

NIFAS /
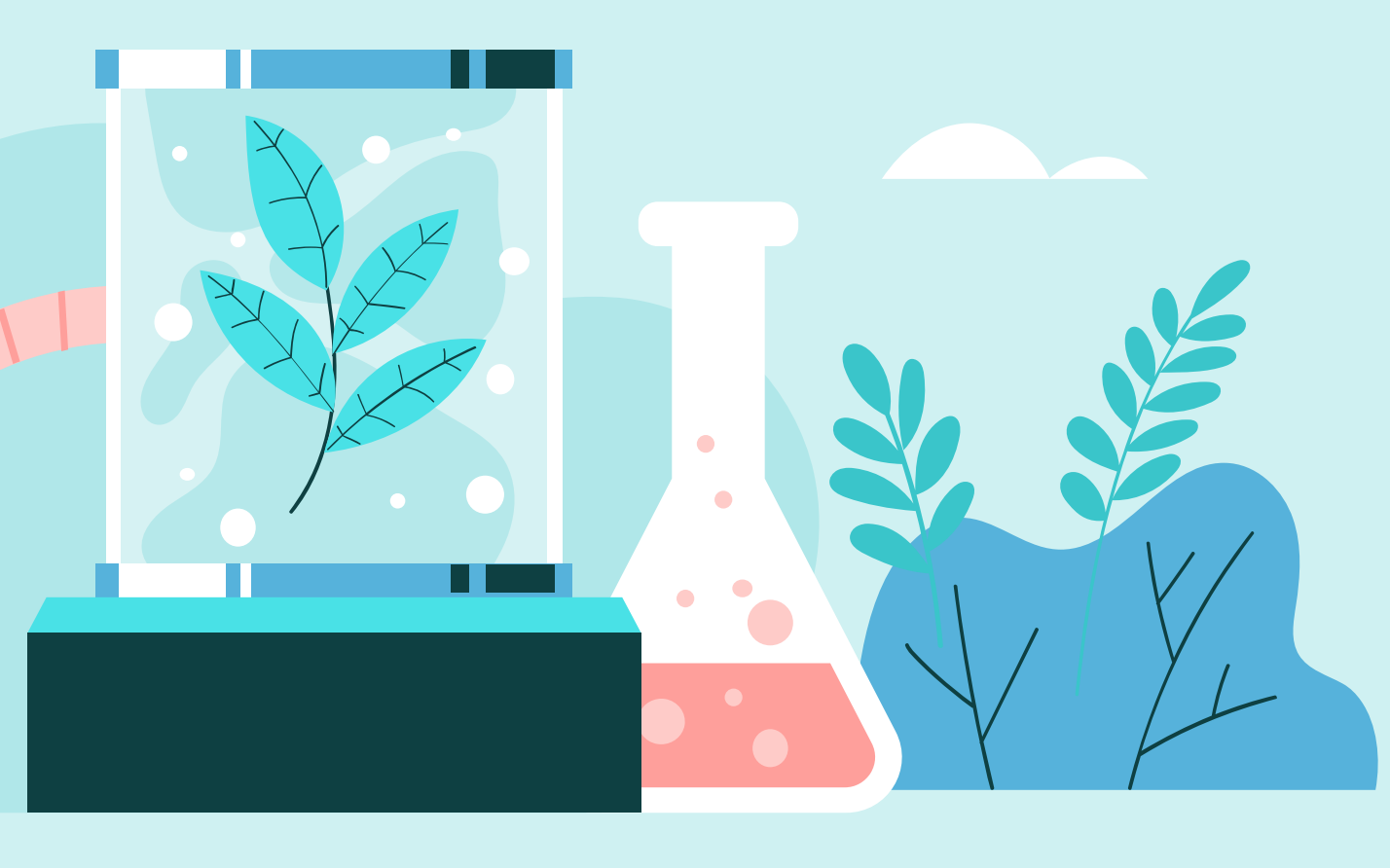


\section{KELOMPOK 6}

MUH ISRAL MARLIS 70200120069

NURUL LATIFAH 70200120029

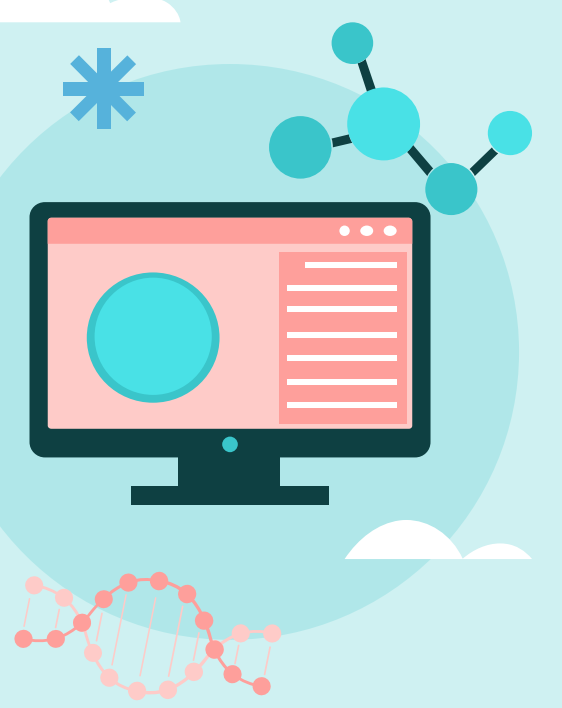

NURUL ATHIRA

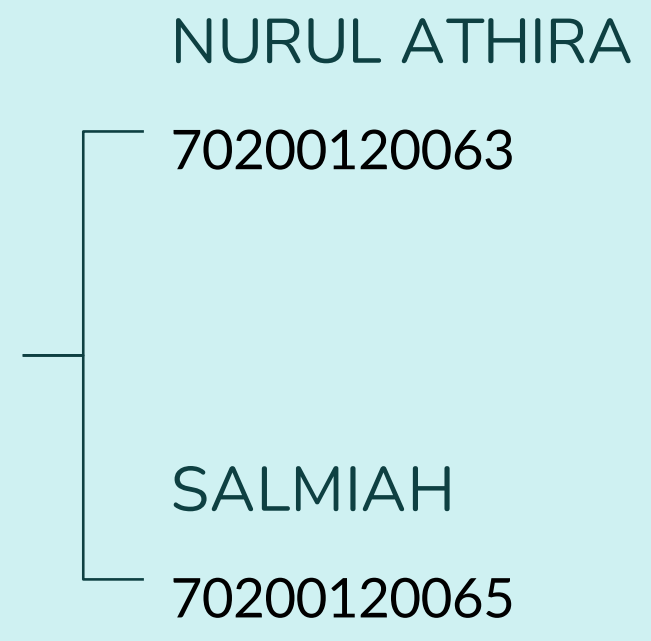




\section{OUTLINE PEMBAHASAN}

PENGERTIAN NIFAS

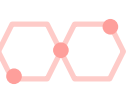

TUJUAN ASUHAN

MASA NIFAS
PENCEGAHAN INFEKSI DAN PEMBERIAN VITAMIN A PADA MASA NIFAS

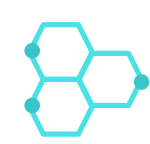

PERUBAHAN PSIKIS DAN FISIK PADA MASA NIFAS

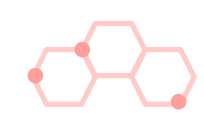

KEBIJAKAN

PROGRAM

NASIONAL MASA

NIFAS 


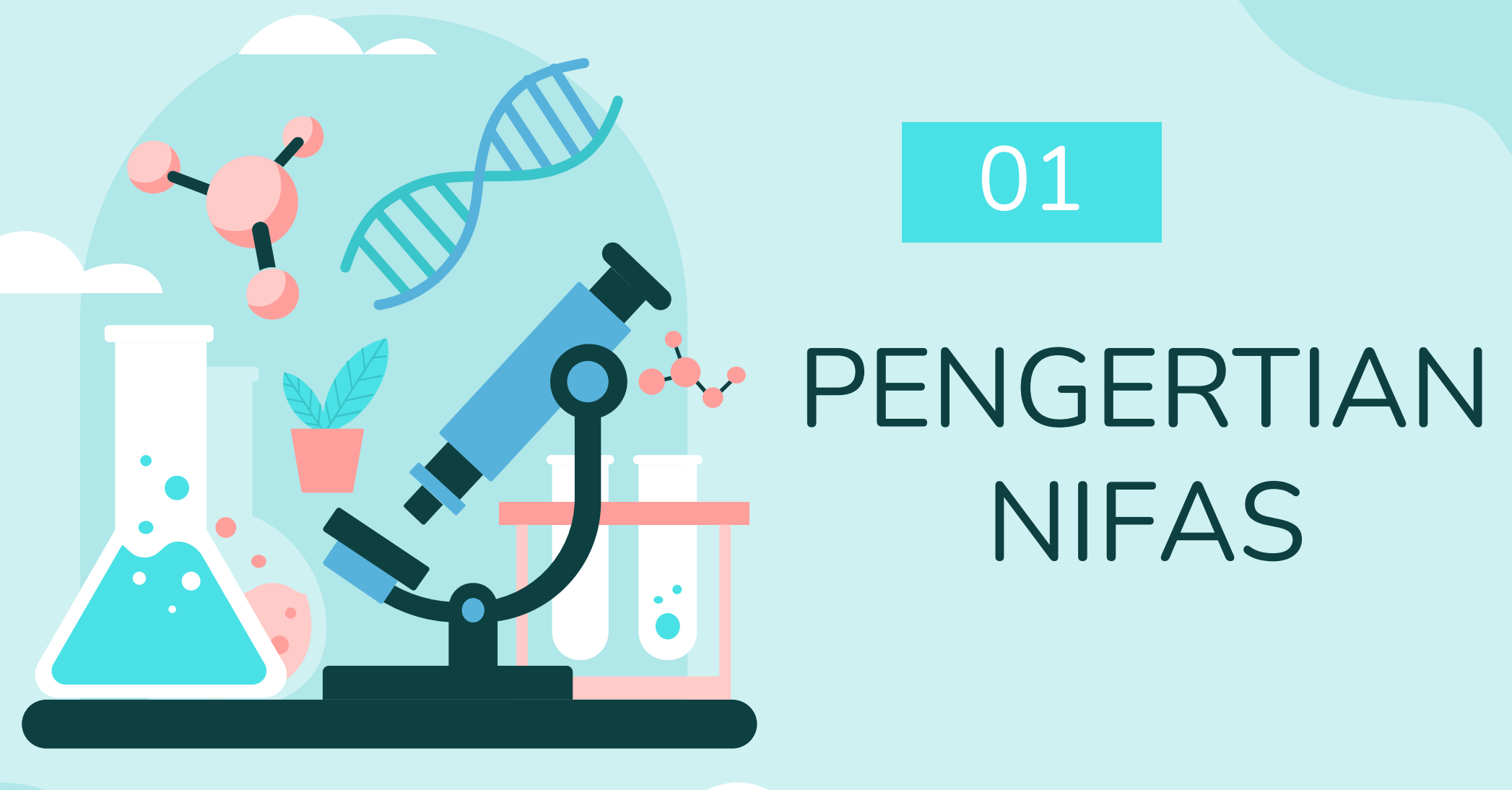


Masa nifas merupakan hal penting untuk diperhatikan guna menurunkan angka kematian ibu dan bayi di Indonesia.

Asuhan masa nifas penting diberikan pada ibu dan bayi, karena Merupakan masa krisis baik ibu dan bayi.
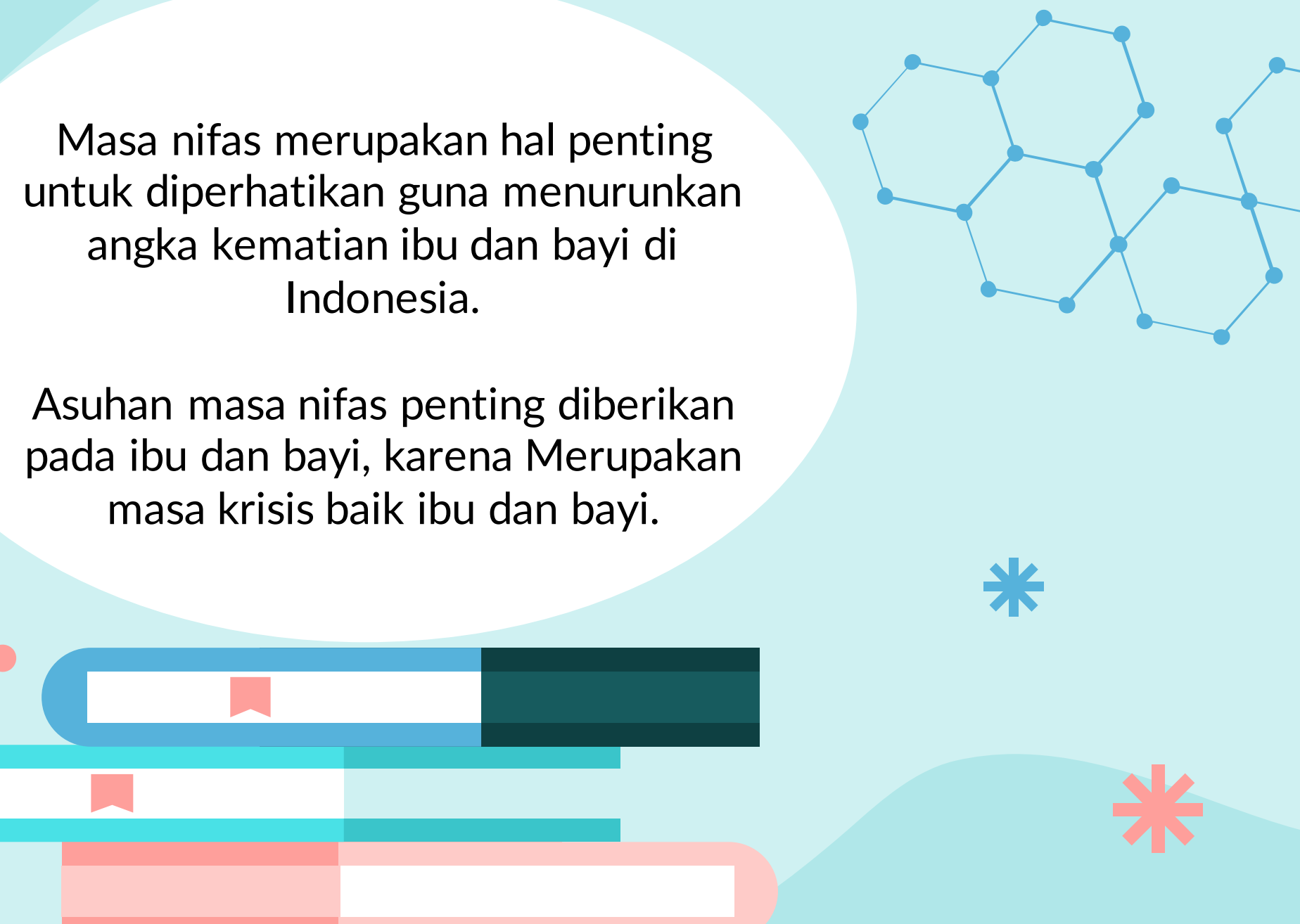


\section{Mansyur, N. (2014)}

Kematian ibu terjadi setelah persalinan, dan $50 \%$

kematian pada masa Nifas terjadi 24 jam pertama.

Demikian halnya dengan masa neonatus Juga merupakan masa krisis dari kehidupan bayi.

Dua pertiga kematian Bayi terjadi 4 minggu setelah persalinan, dan $60 \%$ kematian bayi baru Lahir terjadi 7 hari setelah lahir. 


\section{TAHAPAN MASA NIFAS}

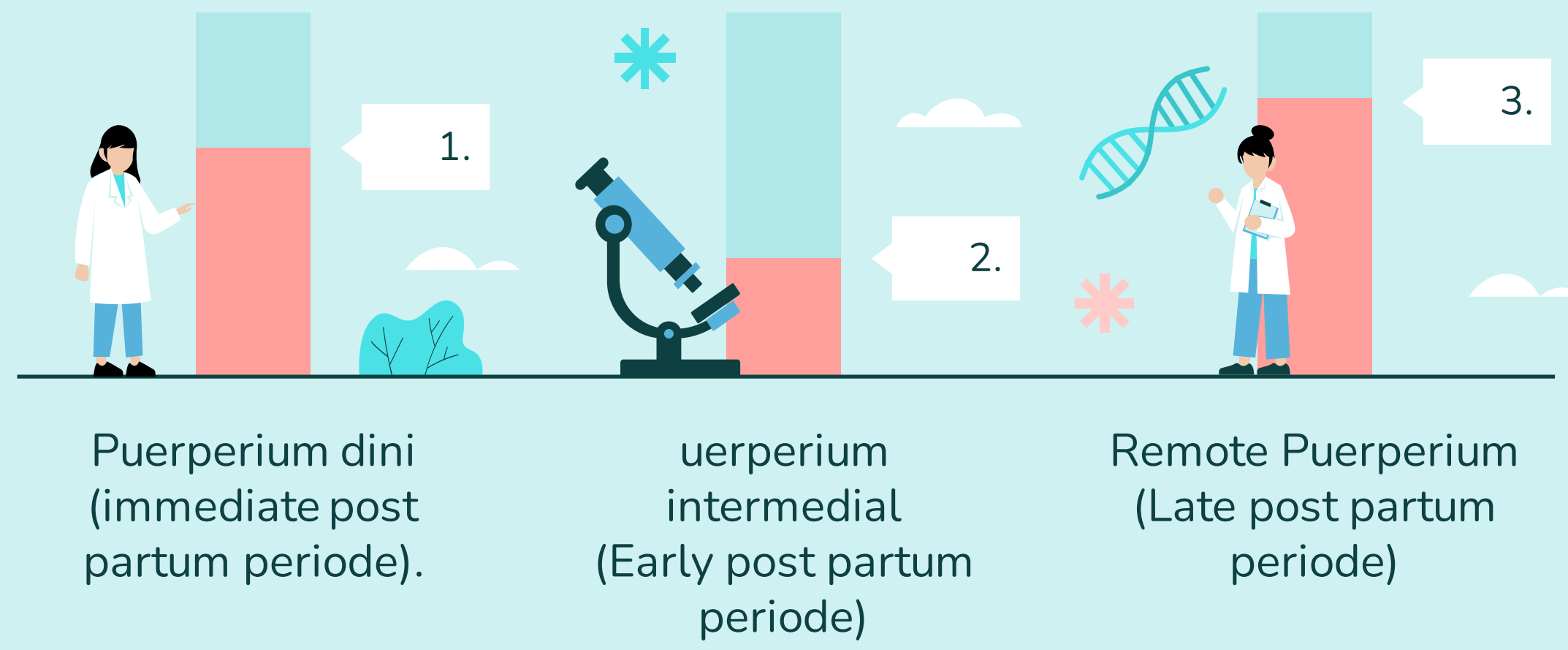




\section{Lanjutan penjelasan......}

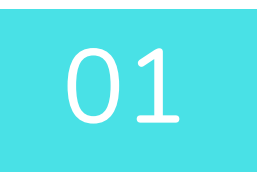

Masa segera setelah plasenta lahir sampai dengan 24 jam, yang dalam Hal ini ibu telah diperbolehkan berdiri dan berjalan-jalan.

\section{2}

Masa 24 jam setelah melahirkan sampai dengan 7 hari (1 minggu). Periode ini bidan memastikan bahwa involusio uterus berjalan normal, tidak ada perdarahan abnormal dan lokhia tidak terlalu busuk.

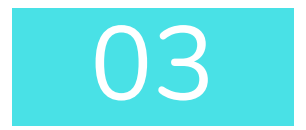

Masa 1 minggu sampai 6 minggu sesudah melahirkan. Periode ini Bidan tetap melanjutkan pemeriksaan dan peraw atan sehari-hari Serta memberikan konseling KB. 


\section{$\mid / / / / / / / / / / /$ \\ PERUBAHAN PSIKIS}

1) Perasaan ibu berfokus pada dirinya, berlangsung stlh melahirkan sampai hari ke 2 (Fase Taking In)

2) Ibu merasa merasa kwatir akan ketidak mampuan merawat bayi, muncul perasaan sedih (Baby Blues disebut Fase Taking Hold (hari ke 3 - 10)

3) Ibu merasa percaya diri utk merawat diri dan bayinya disebut Fase Letting Go. (hari ke 10-akhir masa nifas)
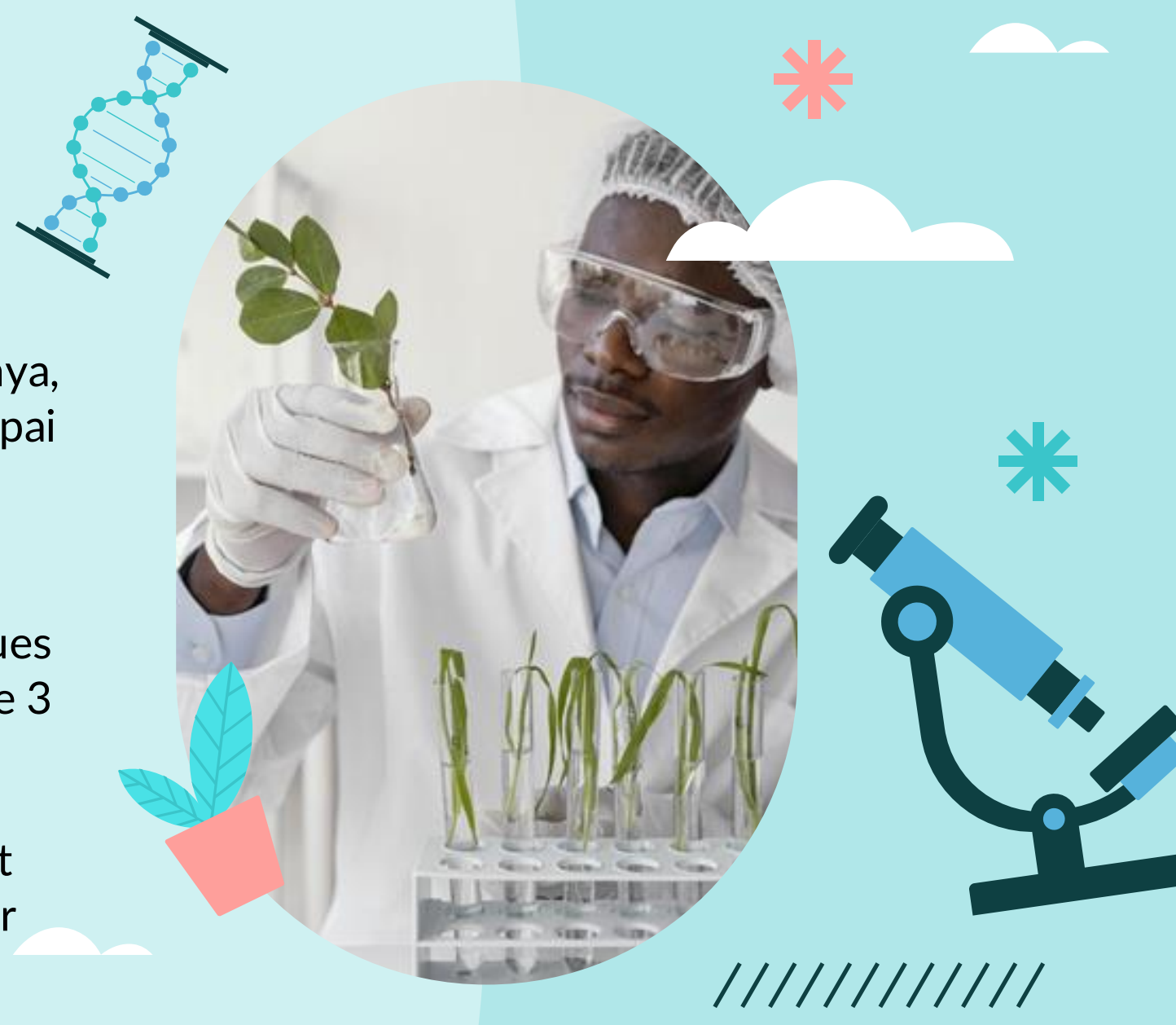
1) Rasa Kram dan mules dibagian bawah perut akibat penciutan rahim (involusi)

2) Keluarnya sisa-sisa darah dari vagina (Lochia)

3) Kelelahan krn proses melahirkan.

4) Pembentukan ASI shg payudara membesar.

5) Kesulitan buang air besar (BAB) dan BAK.

6) Gangguan otot (betis, dada, perut, panggul dan bokong)

7) Perlukaan jalan lahir (lecet atau jahitan)

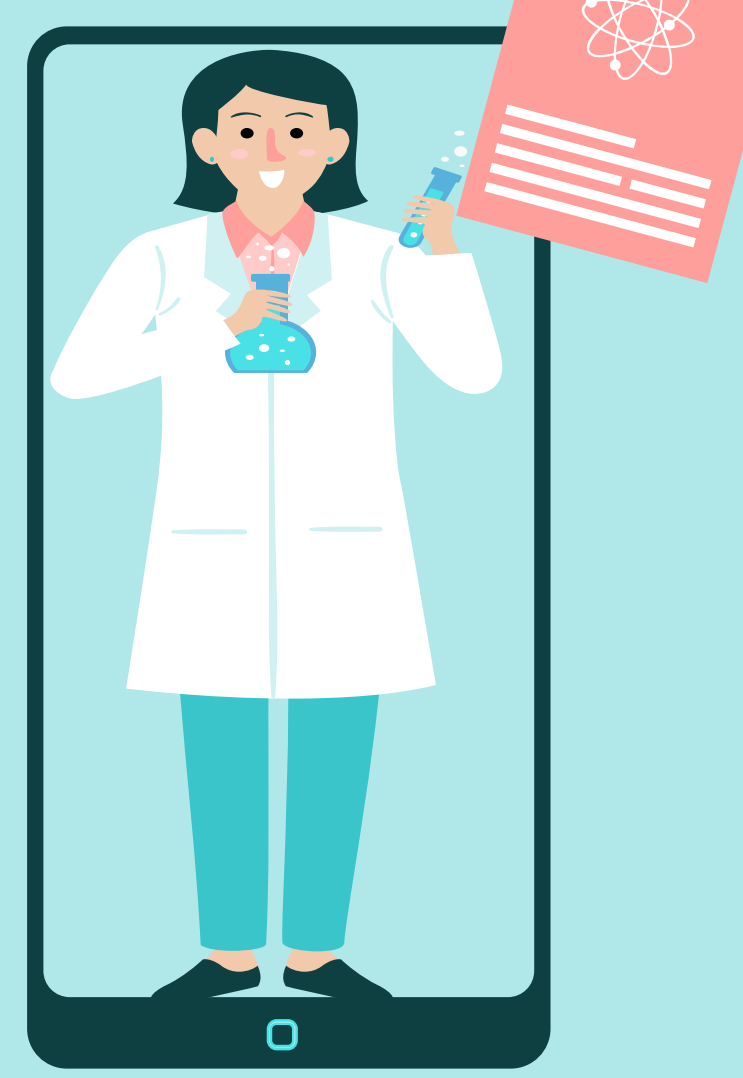




\section{TUJUAN ASUHAN NIFAS}

\section{1}

Membantu ibu dan pasangannya selama masa transisiawal mengasuh anak

\section{4}

Merujuk ke tenaga ahli bila diperlukan.

\section{2}

Menjaga kesehatan ibu dan bayinya, baik fisik maupun psikologis

\section{5}

Mendukung dan

memperkuat keyakinan diri ibu dan memungkinkan

melaksanakan peran sebagai orang tua.

\section{3}

Mencegah dan mendeteksi dini komplikasi pada ibu nifas.

\section{6}

Memberikan pelayanan $\mathrm{KB}$ 


\section{PENCEGAHAN INFEKSI NIFAS}

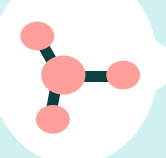

Masa

Kehamilan

Mengurangi atau mencegah faktor-faktor predisposisi seperti anemia, malnutrisi dan kelemahan, serta mengobati penyakitpenyakit yang diderita oleh ibu. Pemeriksaan dalam jangan dilakukan kalau tidak ada indikasiyang perlu.
Masa

Persalinan

-pemeriksaan berulang ulang, lakukan bila ada indikasi dengan sterilitas apalagi bila ketuban telah pecah. - Hindari partus terlalu lama dan ketuban pecah lama. - Jagalah sterilitas kamar bersalin dan pakailah masker, alat-alat harus suci Hindari dalam yang baik, hama.

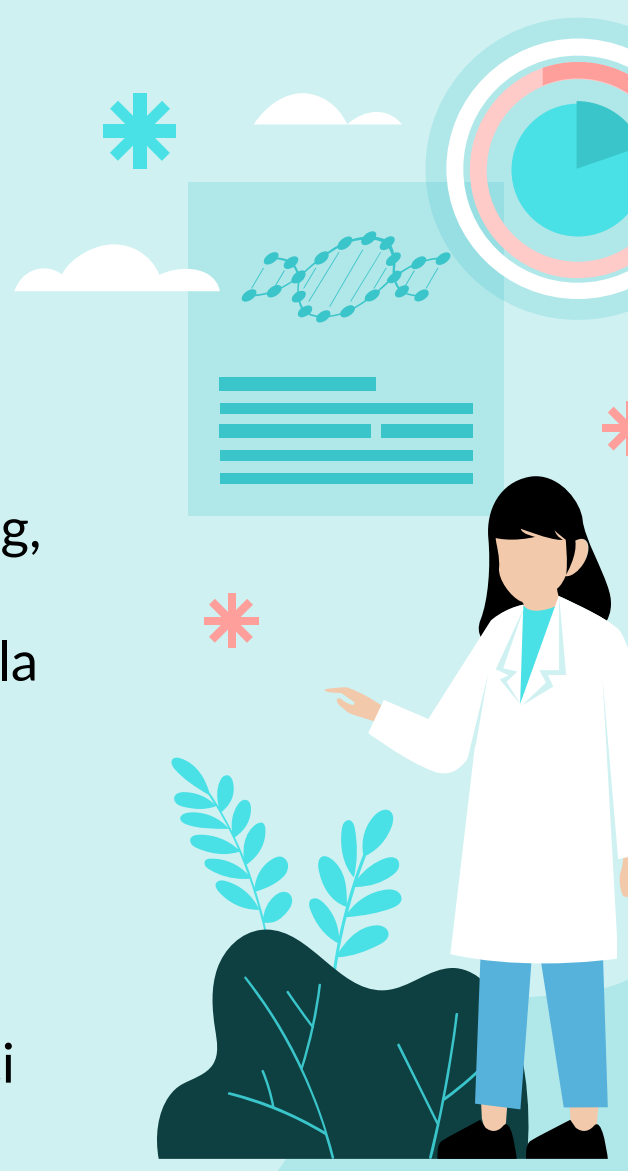




\section{$1 / / / / / / / / / \mid$ \\ PEMBERIAN VITAMIN A}

Vitamin A merupakan suplementasi yang diberikan pada ibu menyusui selama masa nifas yang memiliki manfaat penting bagi ibu dan bayi yang disusuinya dengan dosis pemberian $2 \times 200.000 \mathrm{SI}$. 


\section{LANJUTAN.....}

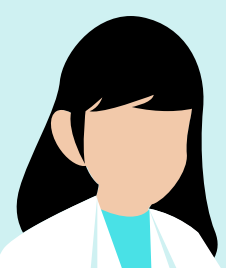

Bagi Bayi Meningkatkan kualitas ASI, Meningkatkan kelangsungan hidup anak dan daya tahan tubuh,

Mencegah komplikasi dari penyakit campak dan diare, Melindungi mata dari xeropthalmia dan buta senja

Bagi Ibu Memelihara kesehatan ibu selama menyusui, Mencegah buta senja karena kurang vitamin $\mathrm{A}$ pemberian yang pertama diberikan segera setelah melahirkan, sedangkan pemberian kedua jarak 24 jam setelah yang pertama dan tidak lebih dari 6 minggu kemudian. 
Kebijakan Program Nasional Masa Nifas

Kujungan nifas dilakukan minimal 4 kali untuk menilai status ibu dan bayi baru lahir dan untuk mencegah, mendeteksi dan menangani masalah masalah yang terjadi.

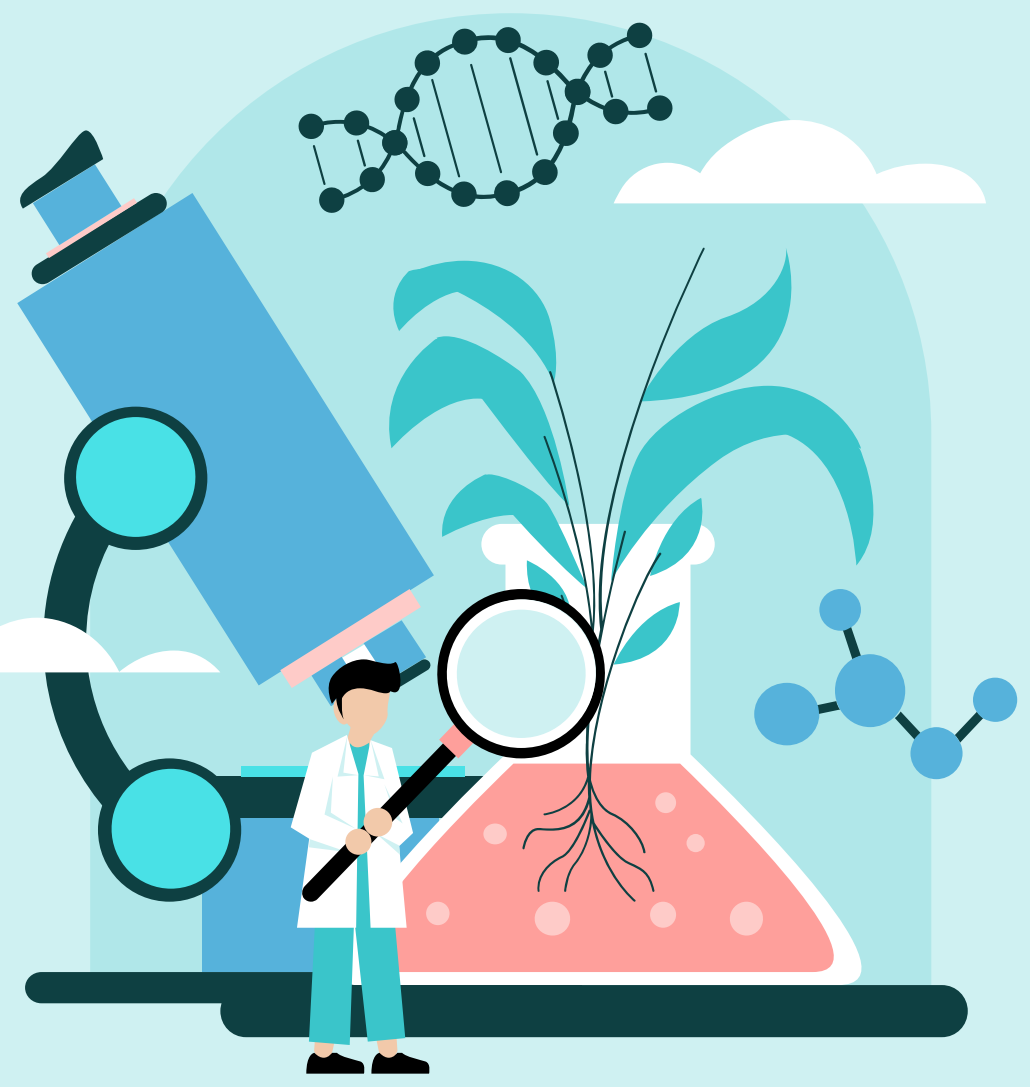




\section{KUNJUNGAN MASA NIFAS}

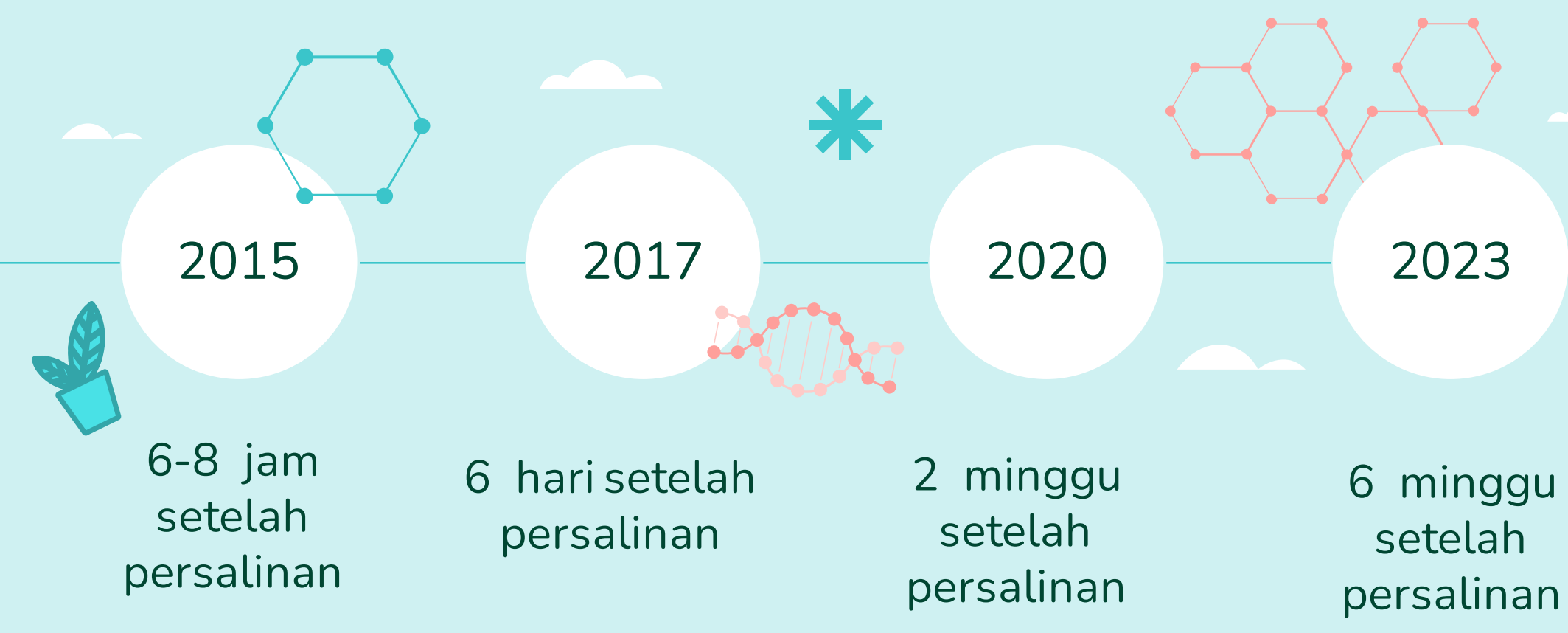




\section{DAFTAR PUSTAKA}

1. Saleha, S. (2009). Asuhan kebidanan pada masa nifas.

2. Mansyur, N. (2014). Buku ajar: Asuhan kebidanan masa nifas.

3. M, FEBI SUKMA. IHIDAYATI, ELL. NURHASIYAHJAMIL, SITI. 2017. ASUHAN KEBIDANAN PADAMASA NIFAS. J. KH Ahmad Dahlan Cirendeu Ciputat 15419: Fakultas Kedokteran dan Kesehatan Universitas Muhammadiyah Jakarta.

4. Khasanah, N. A., \& Sulistyawati, W. (2017). Asuhan Nifas dan Menyusui. E-Book Penerbit STIKes Majapahit, 1-177.

5. E Yulianisa, MS Mardiyah - Jurnal IImiah Kebidanan Indonesia, 2019 journals.stikim.ac.id

6. Janiwarty, B. dan H. Z. Pieter. 2013. Pendidikan Psikologi untuk BidanSuatu Teori dan Terapannya. Rapha Publishing. Yogyakarta. 


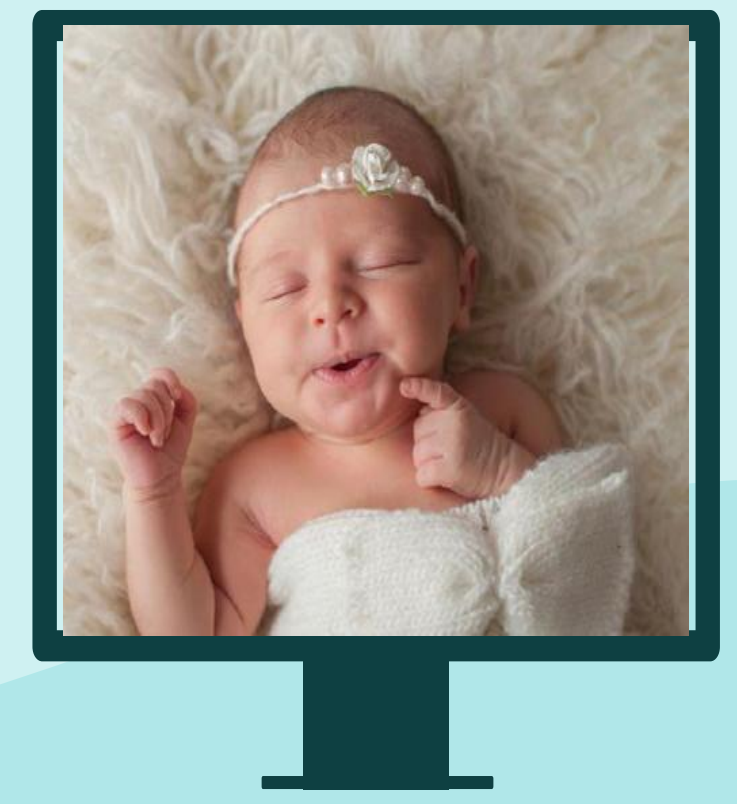

Sembilan bulan mengandung akan menjadi saksi lahirnya anak yang diinginkan dengan tangis, canda dan tawa 
Rahim ibu

Digunting!'Darah Ibu Tumpah! Kepalamu

Ditarik Keluar Melihat Dunia. Ibumu Kesakitan.

Tapi Hadirnya Kamu Adalah Kebahagiaan

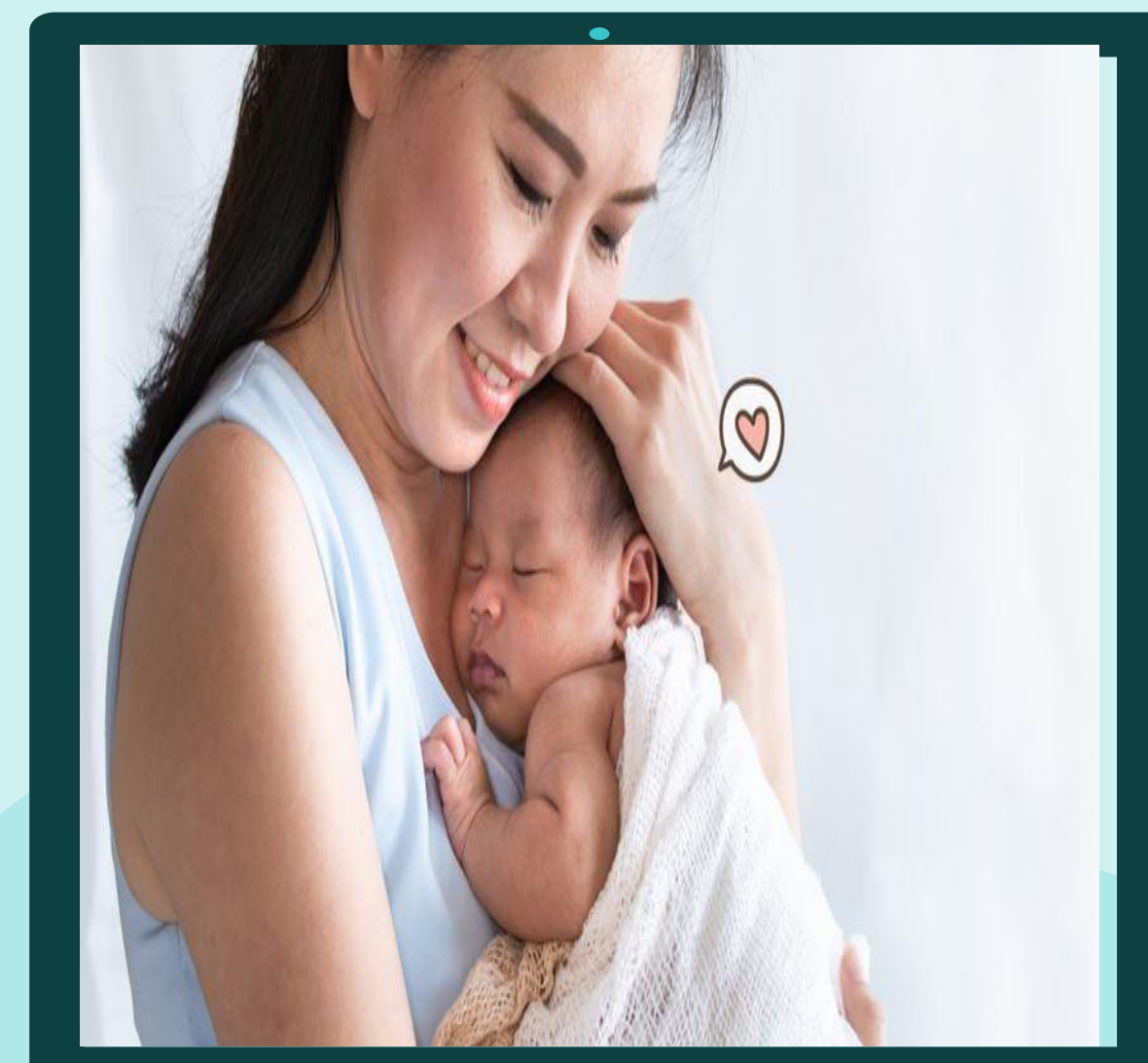


THANK YOU 